\title{
Changes in Cyclone Pattern with Climate Change Perspective in the Coastal Regions of Bangladesh
}

\author{
SM M. Rana, Md. Kamruzzaman, M. A. Rajib and Md. M. Rahman \\ Bangladesh University of Engineering and Technology (BUET)
}

(received in April, 2011, accepted in June, 2011)

\begin{abstract}
Climate change has started to alter the way how climatic events take place on the earth. Occurrence and distribution of extreme climatic events are now more frequent and undoubtedly Bangladesh is experiencing the effects of climate change among which the extreme events manifest in a more evident and devastating way. This paper aims at eliciting evidences of the effect of climate change on the characteristics of cyclones of this region. Recent histories of cyclones that formed at the Bay of Bengal and made landfall on the coasts of Bangladesh, ranging from 1795 to 2009, were studied. Frequency of the cyclones has shown an increasing trend along with their intensity. Frequency of weaker cyclones is decreasing and although intensity of the weaker storm is rising, they are rising at a greater rate for the stronger storms and hence there will be large differences among the intensity of the future cyclones. Storm surges show a positive correlation with the intensity of the storms hence greater storm surges can be expected in the future. Storms tracks seem to remain unaltered for a long tract of time. These analyses implicate the necessity to decelerate climate change and also increase awareness among the highly dense population of the coastal regions of the developing countries to reduce damages due to such extreme events.
\end{abstract}

Keywords: Cyclone, Climate Change, Bangladesh, Coastal Area, Extreme Events.

\section{Introduction}

The perturbation of earth's climate due to the emission of excessive greenhouse gases is now well established. Numerous researches are going on to find out the adverse effects of climate change. Climatologists and scientists are working to find out the links between greenhouse gas emissions and the change of patterns of natural events and hazards. Among the many calamities that climate change is believed to bring along are the extreme events which are also the least understood at present. Unless the effects of climate change are properly accounted for, it becomes very difficult for the policymakers to motivate themselves to take necessary steps to counteract climate change. For the inhabitants of coastal regions cyclones and their associated surges have the most damaging consequence. Bangladesh with a high population density of 1111.1 pop/square $\mathrm{km}$ invariably suffer huge losses in terms of infrastructure, crop and human casualty each time a cyclone hits the coastal region. Cyclones and associated surges combined with sea level rise poses a grave threat of inundation of coastal region with saline water and consequent salinity intrusion in surface and ground water resources which besides destruction of crops and other biodiversity will create acute drinking water problems.

Extensive climate modelings are being undertaken worldwide but modeling of cyclones are yet to reach any satisfactory level due to their extremely complicated processes of formation. Intergovernmental Panel on Climate Change (IPCC) in its four reports so far has provided several predictions on the trend of future cyclones based on results of several models, both global and regional, but still ambiguities remain about the characteristics of future storms. In one model it showed that storm intensity will increase with the $\mathrm{CO}_{2}$ induced warming (Krishnamurti et al., 1998). Study examining large scale atmospheric and oceanic condition suggested small change in the tropical cyclone frequencies about $10 \%$ increase in the Northern Hemisphere and about $5 \%$ decrease in the Southern Hemisphere 
(Royer et al., 1998) Another study shows areas of deep convection that can be associated with tropical cyclone formation would not expand with increases in $\mathrm{CO}_{2}$ due to an increase in the sea surface temperature (SST) threshold for occurrence of deep convection (Dutton et al., 2000). Another study shows decrease in tropical cyclone frequency globally and in the North Pacific but a regional increase over the North Atlantic and no significant changes in maximum intensity (Sugi et al., 2002)

In this report historical data were used to make trend analysis of the cyclones formed in the Bay of Bengal region. Then the results are compared and contrasted with the IPCC predictions. Future trends of cyclones are predicted using these analyses. Frequency analysis was performed using cyclone data from 1901 to 2009. An intensity analysis was performed using data ranging from 1960 to 2009 which portrayed the trend of the strength of the storms in terms of wind speed with time. A seasonal distribution of cyclones from 1795 to 2009 were made dividing a year of the Gregorian calendar into four different seasons viz. pre-monsoon, monsoon, postmonsoon and winter, to portray the tendency of cyclone formation at different seasons.

\section{Data and Methodology}

Primarily cyclone data has been collected from Bangladesh Meteorological Department (BMD), Disaster Management Bureau (DMB) of Bangladesh and also from other internationally published papers. (Murty, T.S. et al., 1986; Khalil, M.G.,1992; Murty, T.S. and El-Sabh, M.I., 1992 and Quadir and Iqbal, 2008) Number of cyclones hitting the coastal region each year from 1901 to 2009 has been tabulated and a frequency analysis has been performed. To find out the trend of intensity of the cyclones, cyclones from the period of 1960 to 2009 was tabulated and graphs of wind speed vs. time were plotted. The whole period was divided into three segments and average intensity was calculated for each segment. Since the second order polynomial best matched the observed data two second order polynomial trend lines for the whole period were drawn using Microsoft Excel through the points above and below the average intensity. The cyclones with intensities above average are termed as "high intensity" cyclones and the ones below are termed as "low intensity" cyclones. A similar plot was made for associated surge heights of the cyclones and the surge heights above and below the average are termed as "high surge" and "low surge" respectively. The trend lines are compared with the averages of two segments of which the first segment, ranging from 1901 to 1990, has been considered as the climatological base period. For seasonal distribution of cyclones, cyclones that hit the coasts of Bangladesh from 1795 to 2009 were tabulated and classified as cyclonic storm $\left(63-87 \mathrm{Kmh}^{-1}\right)$, severe cyclonic storm (88-117 $\left.\mathrm{Kmh}^{-1}\right)$, very severe cyclonic storm(118-221 $\left.\mathrm{Kmh}^{-1}\right)$, super cyclonic storm $\left(>222 \mathrm{Kmh}^{-1}\right)$ according to the Regional Specialized Meteorological Center (RSMC) in New Delhi, India. Bar charts of cyclones showing seasonal distribution were also made for years ranging from 1795-1925, 1926-1960, 19611990 and 1991-2009. Tracks of a total of 20 cyclones hitting the coastal areas of Bangladesh from 1909 to 1991 were analyzed for zone of convergence. According to the landfall of cyclones the coastal areas of Bangladesh was divided into four zones. Zone 1 included Chittagong, Noakhali, Hatiya, Sandwip, zone 2 included Potuakhali, Barguna, Bhola, zone 3 included Shyamnagar, Koyra and southern parts of Sathkhira and Khulna and zone 4 included Cox's bazaar. Frequency of Cyclones

Current knowledge and available techniques are not able to provide robust quantitative indications of potential changes in tropical cyclone frequency. The modest available evidence points to an expectation of little or no change in global frequency. Regional and local frequencies could change substantially in either direction, because of the dependence of cyclone genesis and track on other phenomena (e.g. El NiñoSouthern Oscillation) that are not yet predictable. (Henderson-Sellers et al., 1998) Here a graphical method of study has been adopted to find out any indication of change of cyclone frequency.

The number of cyclones hitting the coasts of Bangladesh from 1901 to 2009 has been shown in Fig 1. It is observed that the cyclones are hitting the coasts of Bangladesh very frequently in the recent decades. During the period of 1901-1960 very few cyclones were formed but from 1960 cyclones started to hit coastal areas of Bangladesh very frequently. A massive cyclonic activity can be seen in the period between 1960 and 1978. From 1979 the high amount of cyclone formation ceased but cyclones kept forming on a regular basis with one or two years in between. From 1901-1957 only 11 cyclones hit the coastal areas, while after 1957 till 2009 total 55 cyclones hit the coastal areas of Bangladesh. So, in the last 52 years number of cyclones hitting coastal areas of Bangladesh has increased 5 times than the previous 57 years.

Several predictions for cyclone can be found both in the third and fourth assessment reports by IPCC that states decrease in cyclone frequency for a warming climate. One study stated that the frequency of global tropical cyclone occurrence did not change significantly, but the mean intensity of the global tropical cyclones increased significantly (Tsutsui, 2002). In a frequency study by Hennon, P. et al. (2010) Bay of Bengal has been found to be the second most frequently visited place in the world by cyclones with about 20 cyclones per decade. In that study cyclone data from 1945 to 2007 were used. In a review article by Knutson, T.R. et al. (2010) it is stated that late twenty-first-century modeling studies consistently projects decrease in globally averaged frequency of tropical cyclones (by 6-34\%). And on the other hand higher resolution modeling studies typically indicate an increase in the frequency of high intensity storms. It is also stated that for individual 
basins uncertainties in the projection of tropical cyclone frequency are much higher - about $\pm 50 \%$ or more by various models.

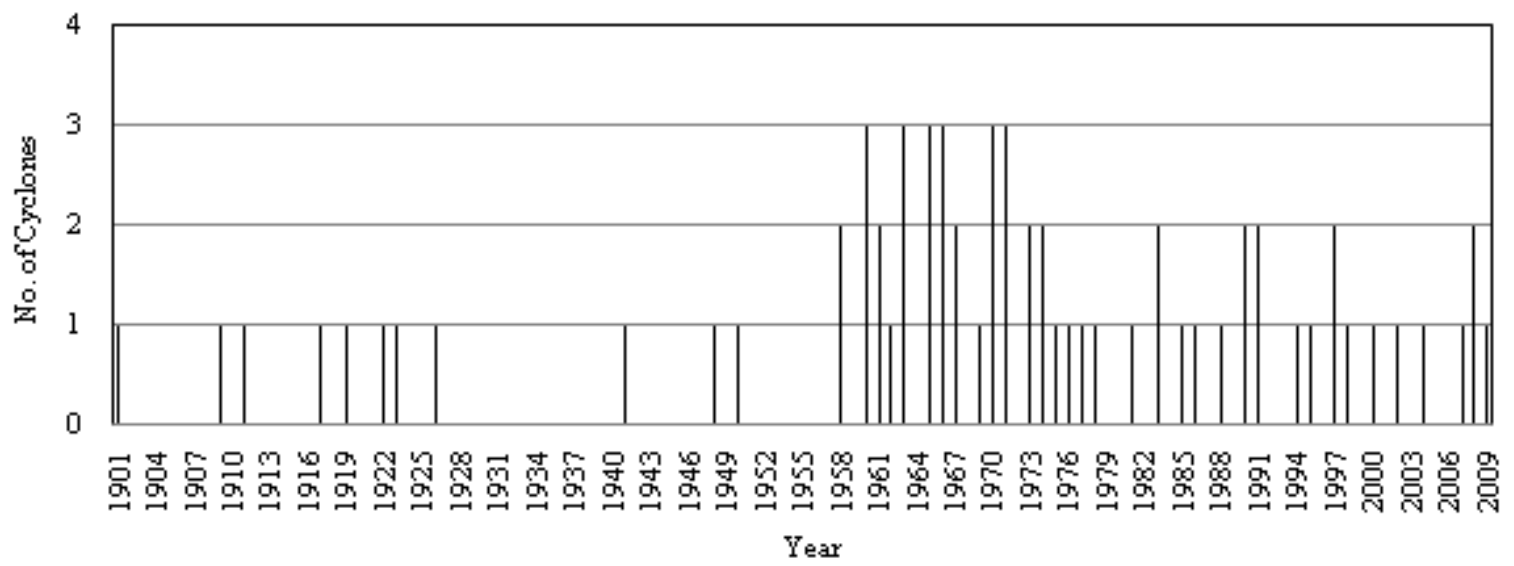

Fig. 1. Number of cyclones making landfall on the coasts of Bangladesh each year from 1901 to 2009

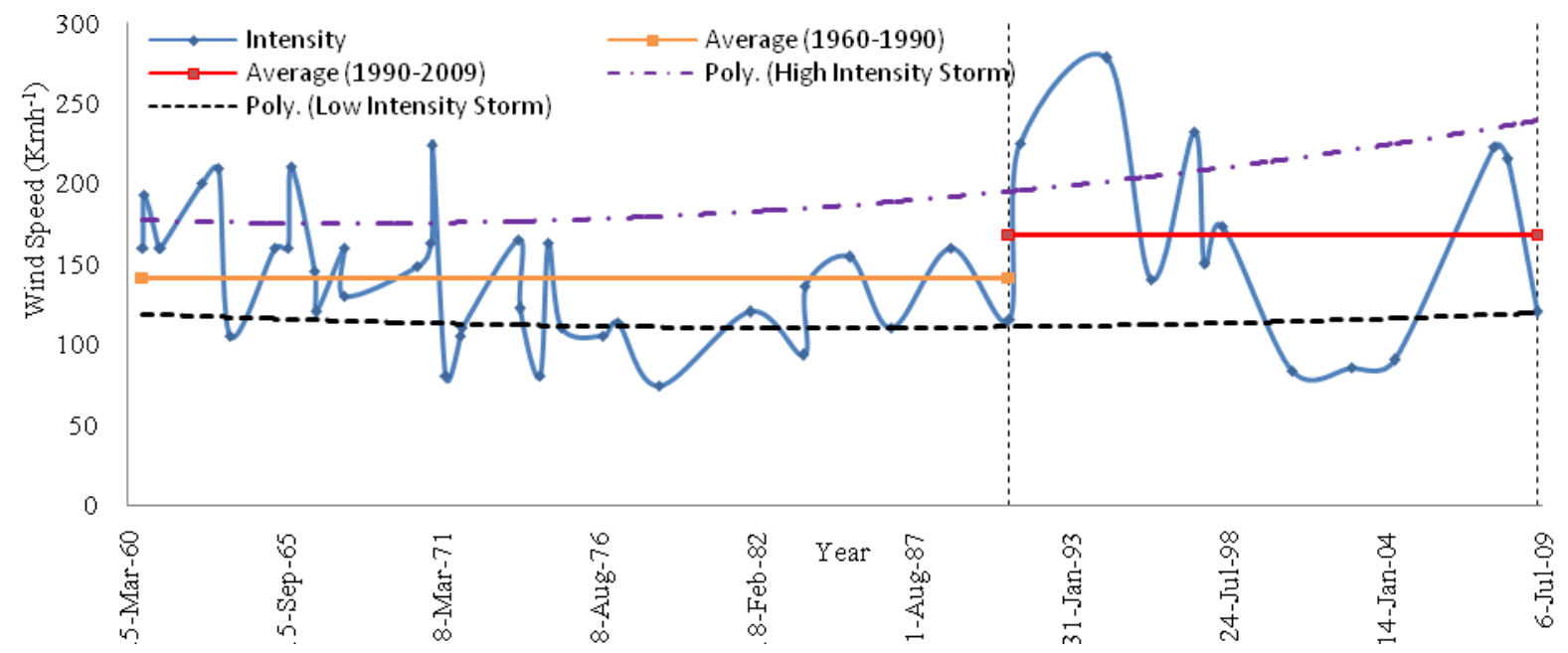

Fig 2. Intensity of cyclones along with their averages and polynomial trend lines

Table 1. Percentage deviation of trend lines of intensity of cyclones from the average

\begin{tabular}{|c|c|c|c|c|c|c|}
\hline Segment & Average & Date & $\begin{array}{l}\text { Trend line value of } \\
\text { high intensity storm }\end{array}$ & $\begin{array}{l}\% \text { Deviation } \\
\text { from Average }\end{array}$ & $\begin{array}{l}\text { Trend line value of } \\
\text { low intensity storm }\end{array}$ & $\begin{array}{c}\% \text { Deviation from } \\
\text { Average }\end{array}$ \\
\hline \multirow{5}{*}{1} & \multirow{5}{*}{141} & 15 Sept, 1965 & 165 & 17.02 & 115 & -18.44 \\
\hline & & 8 March, 1971 & 180 & 27.66 & 112 & -20.57 \\
\hline & & 28 August, 1976 & 179 & 26.95 & 111 & -21.28 \\
\hline & & 18 February, 1982 & 180 & 27.66 & 110 & -21.99 \\
\hline & & 11 August, 1987 & 182 & 29.08 & 109 & -22.70 \\
\hline \multirow{4}{*}{2} & \multirow{4}{*}{168} & 31 January, 1993 & 200 & 19.05 & 110 & -34.52 \\
\hline & & 24 July, 1998 & 210 & 25.00 & 112 & -33.33 \\
\hline & & 14 January,2004 & 222 & 32.14 & 112 & -33.33 \\
\hline & & 6 July,2009 & 240 & 42.86 & 115 & -31.55 \\
\hline
\end{tabular}

\section{Intensity Analysis}

Fig 2 shows the trend lines of high intensity cyclones and low intensity cyclones and also the average of the two periods. The average of the second segment is $19.1 \%$ higher than the average of the first segment. It is also observed that both the trend lines are concaved upward indicating an increase in the intensity of both high intensity storms and low intensity storms.

The trend lines are deviating away from each other suggesting there would be higher variability in the intensity amongst future storms: the gap between strong and weak storms will increase. Deviation of the trend lines from the average is increasing for high 
intensity cyclones and decreasing for low intensity cyclones as can be seen in Table 1 .

\section{Surge Height Analysis}

Storm surges bring about long term suffering for coastal populations. Associated surge of the cyclone Aila in 2009 caused massive damage to crops and drinking water systems of the coastal population of Bangladesh. Lands still remain barren today and people have to rely on aids and rainwater for their drinking. A surge height trend analysis similar to that of intensity analysis is shows in Fig 3. Trend lines for surge height also are concaved upward. The trend line for high surges shows less curvature than the trend line for the low surges. Also from Fig 4 a positive correlation between surge height and wind speed can be observed. Associated surge height of a cyclone does not only depend on the intensity of a cyclone but also on the other factors viz. depth of water, tide, islands, coastal resistance by forests, size of the storm, embankments etc. However, it can still be averred that with the increasing trend of intensity of the cyclones in a future warmer climate, higher storm surges can be expected.

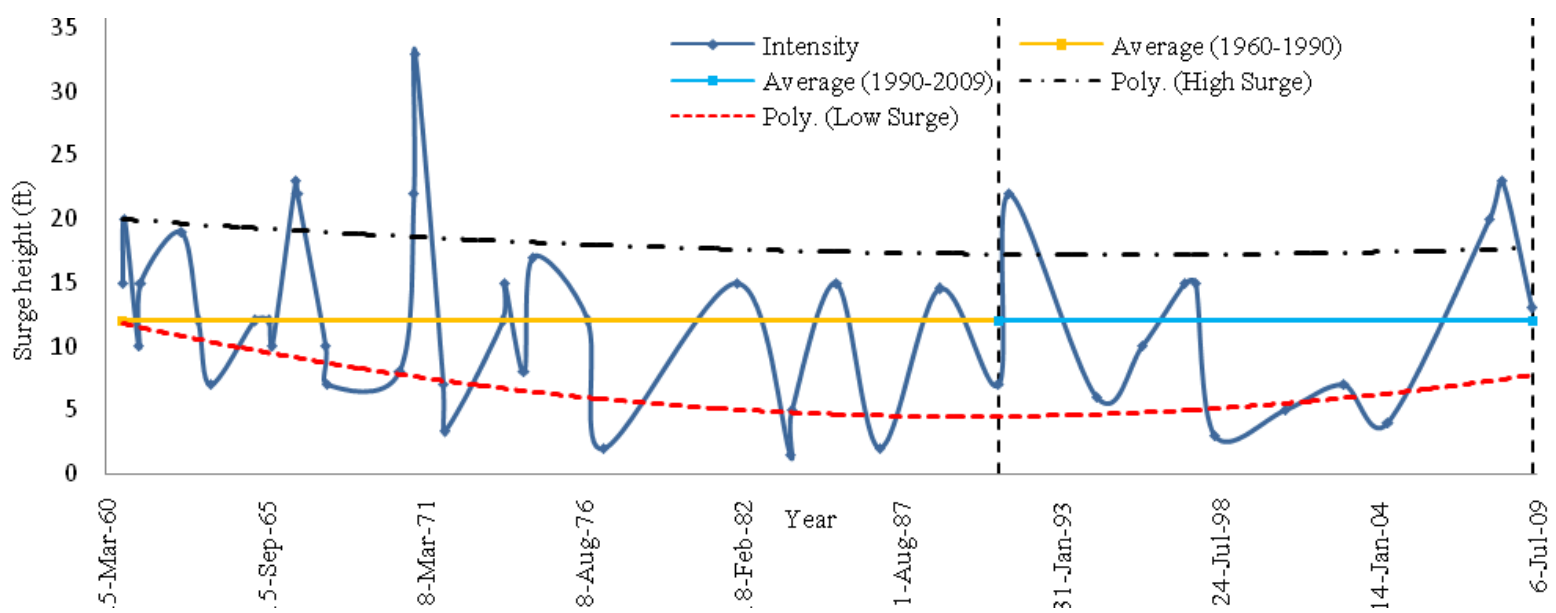

Fig 3. Surge height measured for different storms along with their polynomial trend lines

\section{Seasonal Distribution of Cyclones}

Fig 5 shows how the cyclones were distributed among the four main seasons of Bangladesh. The number inside the bars represents the number of cyclones of a specific category also represented by their specific color. The four seasons of Bangladesh are pre-monsoon (March, April and May), monsoon (June, July, August and September), post-monsoon (October and November) and winter (December, January and February). It can be seen from the bar charts that for a large tract of time, from 1795-1910, cyclones were hitting the coasts mostly during the post-monsoon season. From 1911 to 1930 the cyclones were hitting during the pre-monsoon period instead of the post monsoon period. From 1951 to 1970 and from 1971 to 1990 prevalence of cyclone in the post-monsoon period is re-established and number of cyclones during pre-monsoon coming second. During 1795-1950 the cyclones were mainly cyclonic storm or severe cyclonic storm but after 1950 very severe cyclonic storm started to form and after 1970 super cyclonic storm started forming. In the last two decades heavy cyclonic activity is observed in the premonsoon season and in these two decades four super cyclones formed out of the five super cyclones from 1975-2009. It is evident from these charts that higher number of cyclones has started forming in this region in the recent years, with an increase in the formation of stronger cyclones and a decrease in the formation of the weaker cyclones. A similar result was obtained from the intensity analysis. In the intensity analysis it was seen that the trend line of the low intensity storms was curved upward indicating a transformation of weaker storms to stronger storms i.e. cyclones will be converted to severe cyclones, severe cyclones will be converted to very severe cyclones and so on and hence the absence of weaker storms in recent decades.

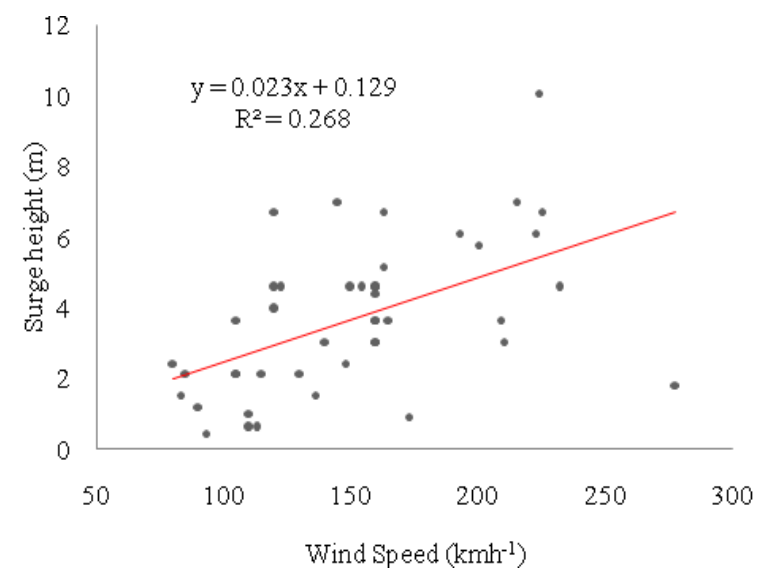

Fig 4. Correlation between surge height and wind speed 

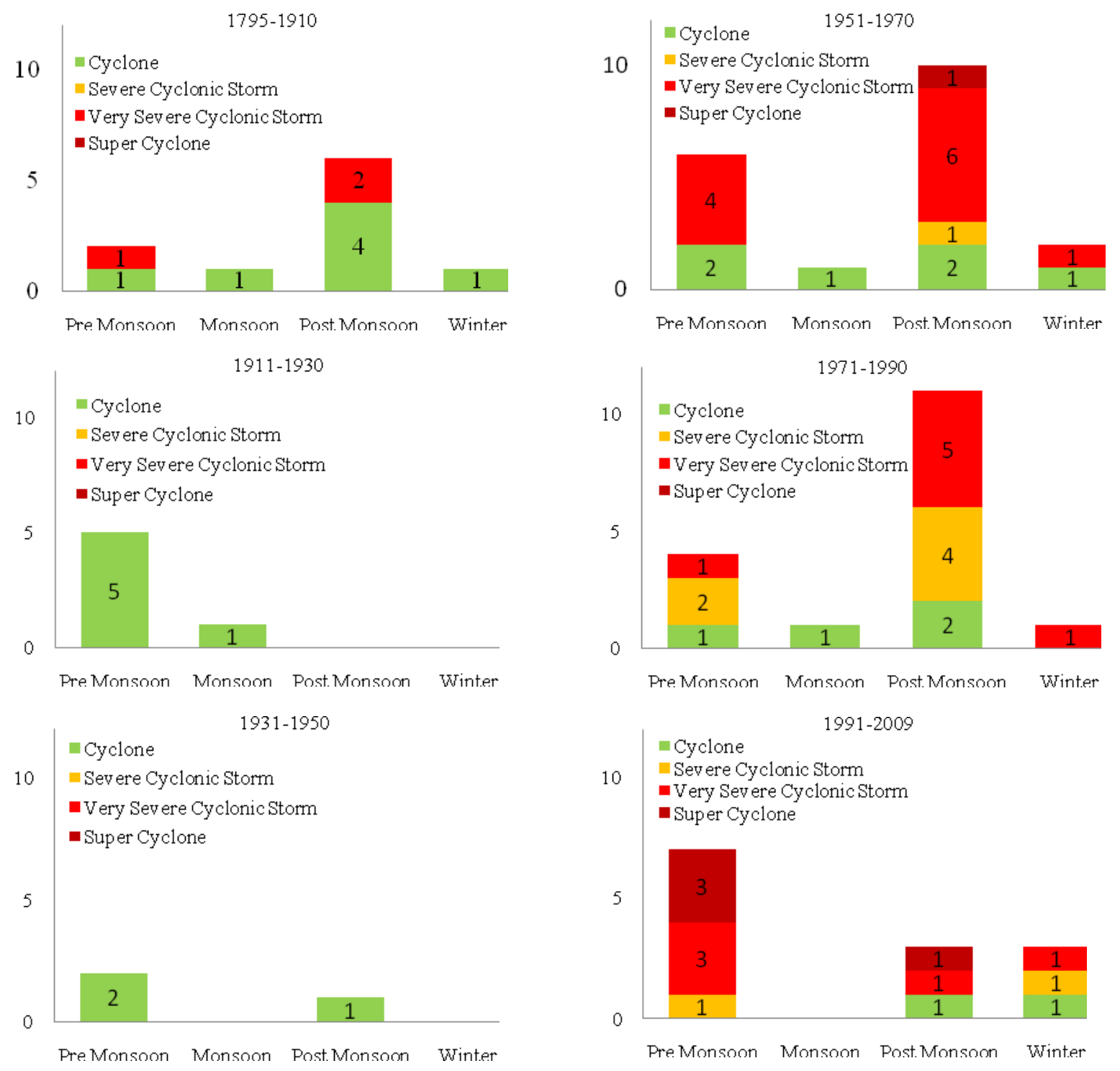

Fig 5 .

Bar charts showing seasonal distribution of cyclones from 1975 - 2009

A model study by Bengtsson et al. (2006) stated that there will be little change in overall numbers of tropical storms but a slight decrease in mediumintensity storms in a warmer climate. Other studies also support this finding like that of Webster et al (2005) which states that there has been a substantial global increase (nearly 100\%) in the proportion of the most severe tropical cyclones (category 4 and 5 on the Saffir-Simpson scale), from the period from 1970 to 1995, which has been accompanied by a similar decrease in weaker systems.

\section{Track Trend of Cyclones}

Fig 6 portrays the tracks of 20 cyclones that made landfall between 1909 and 1991. It is observed that most of the cyclones converge to some particular region of Bangladesh depending upon the location of their formation. These areas of convergence marked by repetitive crossing of cyclones are marked with circles and are areas which are more vulnerable to cyclones and hence their adaptive measures require special attention. It is observed that about $37 \%$ of all the cyclones entering approximately through $88^{\circ}$ to $89.5^{\circ}$ longitudes, converges to zone 4 and the rest (63\%) converges to zone 2 . The cyclones those enter Bangladesh through $89.5^{\circ}$ to $91^{\circ}$ longitudes divides into two part and approximately $75 \%$ of these cyclones converges to zone 1 and $25 \%$ of these cyclones converges to zone 4 . For Bangladesh with respect to cyclones, zone 1 and zone 2 are found most frequently hit by the cyclone hence more vulnerable than other areas.

\section{Damage Scenarios}

The gravest aspect of the cyclones hitting the coastal areas of Bangladesh is that they invariably take away lives of hundreds. Extremely high casualties resulted in the cyclone of 1970 when 470 thousand people died which is greater than sum total of all the other casualties of other storms. (See Fig 7) 
Very recently the cyclone Sidr in 2007 claimed 3447 lives. A very disturbing upward trend can be seen in the loss of lives in the coastal regions. Lack of awareness, lack of training and inadequate institutional management and adaptation methods are the primary reasons for the loss of life every time a cyclone hits the country.

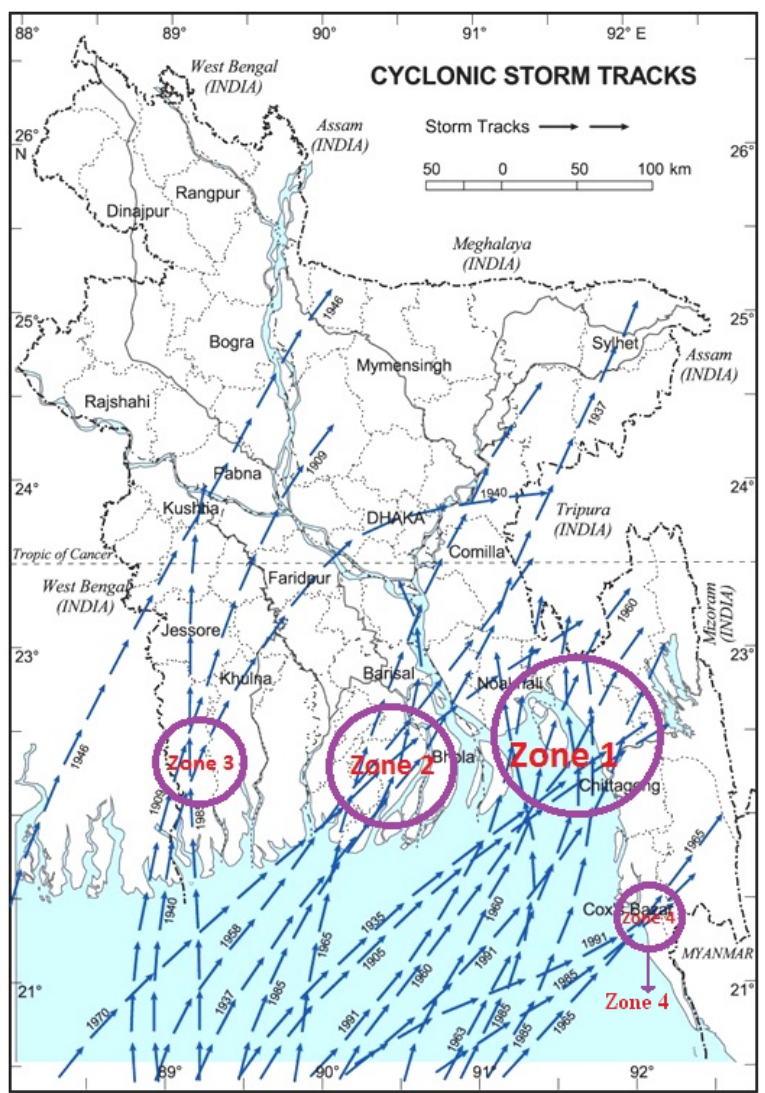

Fig 6. Map of Bangladesh showing tracks of cyclones occurring from 1909 to 1991

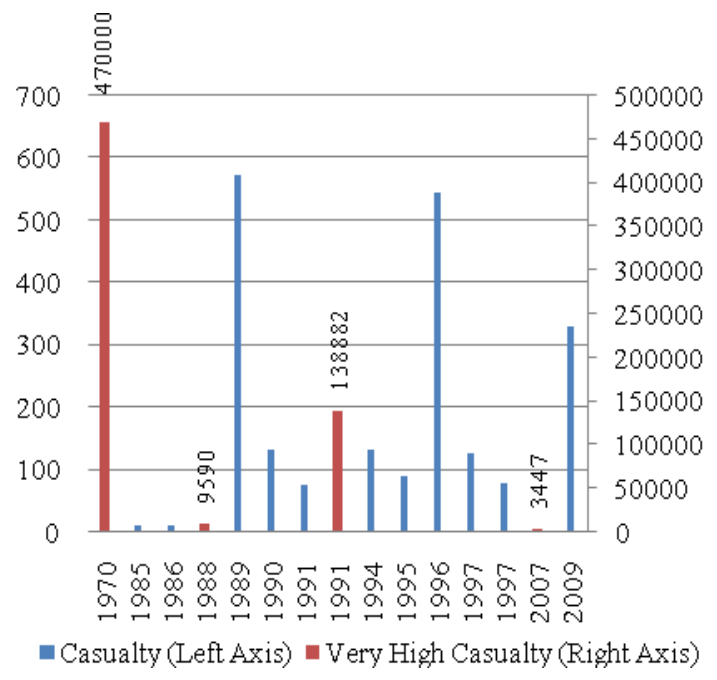

Fig 7. Bar charts showing major casualties in some catastrophic cyclones (Source: Banglapedia, 2010)

Loss of livestock is one of the most crucial damages that people in the coastal region has to suffer. In Bangladesh the coastal regions are inhabited largely by the poorest section of the community who are dependent almost fully on fishing, farming and livestock for their livelihood. Loss of livestock is associated with every cyclone and great losses were incurred by the people in the cyclonic events of 1988 , 1991 and 2007. Reluctance in providing any proper shelter for livestock is prevalent among the authority. The reluctance of the coastal people to leave their livestock behind has been cited as one of the major reasons of human casualty during cyclones. Some major livestock losses are shown in Fig 8.

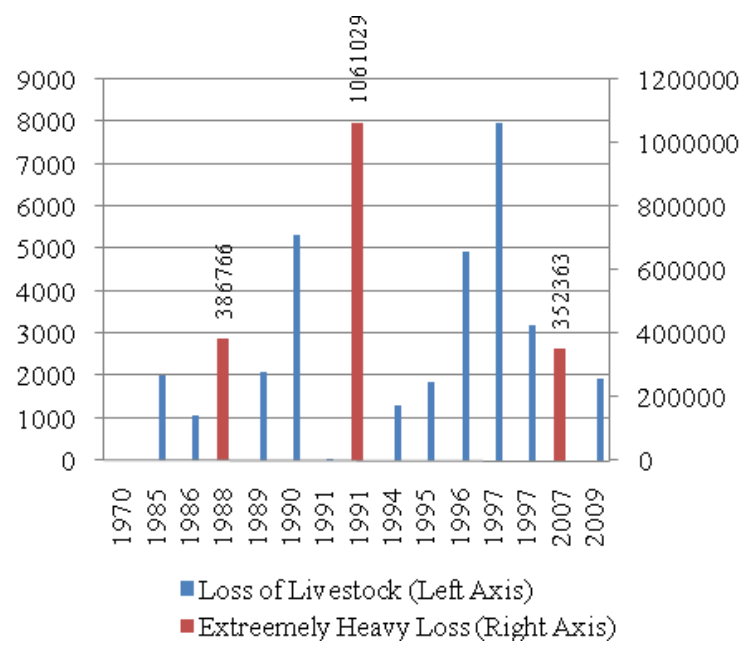

Fig 8. Bar charts showing major livestock losses

\section{Conclusions}

The analysis of historical data of cyclones resulted in alarming trends of future cyclones. The study provided indication that frequency of cyclones will increase while the number of weak cyclones will diminish due to their transformation into stronger cyclones. Super cyclones will be more common in a future warmer climate. Associated surge heights have shown propensity to be higher and fiercer with the increase in intensity of the cyclones. Pre-monsoon and monsoon seasons are seasons to be wary about since most cyclonic activities are formed in these two seasons. Tracks of cyclones seem to remain unaltered. Even with state of the art forecasting system and cyclone monitoring systems there is no sign of reduction of damages caused by the cyclones. And with cyclones expected to make land fall every year it is unacceptable to be expecting huge damages to be incurred by the indigent inhabitants of the coastal regions. It is impossible to relocate such huge mass of population and hence only option available is to be able to adapt and live with the cyclones. Adaptive measures in facing the cyclones have to be more compatible with the changing climate. 


\section{Acknowledgement}

The entire study has been conducted under the British Council funded Higher Education Link Programme (BC-HELP) in BUET.

\section{References}

BANGLAPEIDA. Last cited on May 25, 2011. http://www.banglapedia.org/httpdocs/HT/C 0397.HTM

BENGTSSON, L., K.I. HODḠES, and E. ROECKNER, 2006: Storm tracks and climate change. $J$. Clim., 19, 3518-3543.

DUTTON, J.F., C.J. POULSEN, AND J.L. EVANS, 2000: The effect of global climate change on the regions of tropical convection in CSM1. Geophys. Res. Lett., 27, 30493052

HENDERSON-SELLERS, A., ZHANG, H., BERZ, G., EMANUEL, K., GRAY, W., LANDSEA, C., HOLLAND, G., LIGHTHILL, J., SHIEH, S.-L., WEBSTER, P., MCGUFFIE, K. 1998: Tropical Cyclones and Global Climate Change: A Post-IPCC Assessment. Bull. Amer. Meteor. Soc., 79, 19-38.

HENNON, P., KRUK, M., LEVINSON, D. 2010. Investigating changes in global tropical cyclone storm frequency and intensity. In: Shifting Shorelines: Adapting to the Future, The 22nd International Conference of the Coastal Society, June 13-16, 2010, Wilmington, North Carolina.

KHALIL, G.Md., 1992, Cyclones and Storm Surges in Bangladesh: Some Mitigative measures, Natural Hazards, 6, 11-24

KNUTSON, T. R., MCBRIDE, J.L., CHAN, J., EMANUEL, K., HOLLAND, G., LANDSEA, C., HELD, I., KOSSIN, J.P., SRIVASTAVA, A.K., and SUGI, M., 2010. Tropical cyclones and climate change. Nature Geo., 3, 157163

KRISHNAMURTI, T.N., R. CORREA-TORRES, M. LATIF AND G. DAUGHENBAUGH, 1998. The impact of current and possibly future SST anomalies on the frequency of Atlantic hurricanes. Tellus, 50A, 186-210.

MURTY, T.S. and EL-SABH, M.I., 1992. Mitigating the effects of storm surges generated by tropical cyclones: A proposal, Natural Hazards 6(3), 251-273.

MURTY, T.S., FLATHER, R.A., and HENRY, R.F., 1986. The Storm Surge Problem in the Bay of Bengal, prog. Oceanog., vol.16, 195-233.

QUADIR, D. A. and IQBAL, M.A., 2008. Tropical

Cyclones: Impacts on Coastal Livelihoods,

IUCN Working Paper.

ROYER, J.-F., F. CHAUVIN, B. TIMBAL, P ARASPIN AND D. GRIMAL, 1998. A GCM study of the impact of greenhouse gas increase on the frequency of occurrence of tropical cyclones. Clim. Change, 38, 307-343.

SUGI, M., A. NODA, AND N. SATO, 2002: Influence of the global warming on tropical cyclone climatology: An experiment with the JMA global model. $J$. Meteorol. Soc. Japan, 80, 249-272.

TSUTSUI, J., 2002: Implications of anthropogenic climate change for tropical cyclone activity: A case study with the NCAR CCM2. J. Meteorol. Soc. Japan, 80, 45-65.

WEBSTER, P.J., G.J. HOLLAND, J.A. CURRY, AND H-R. CHANG, 2005: Changes in tropical cyclone number, duration and intensity in a warming environment. Science, 309, 1844-1846.
SM Masud Rana, Postgraduate research assistant at the Bangladesh University of Engineering and Technology.

Research area: Impacts of climate change on coastal population, ground water modeling, coastal hydrology.

Address: Bangladesh University of

Engineering and Technology,

Dhaka-1000, Bangladesh

Phone: $\quad+88-01815000543$

Email: sm.masudrana@gmail.com

Md. Kamruzzaman, Postgraduate research assistant at the Bangladesh University of Engineering and Technology.

Research area: Climate change and its social impact, surface water modeling, sewage treatment.

Address: Bangladesh University of

Engineering and Technology,

Tel: Dhaka-1000, Bangladesh $+88-01729604776$

Email:_zaman_buet@yahoo.com

Mohammad Adnan Rajib, lecturer at the
Bangladesh University of Engineering and Technology.

Research interest: Global and regional climate modeling, conjunctive hydrodynamic-climate change modeling of watersheds, multi-dimensional surface water modeling, fate and transportation of contaminants, sediment transport, remedial strategies of groundwater contaminants, air pollution air quality modeling.

Address: Bangladesh University of

Engineering and Technology,

Tel: $\quad+88-01927612181$

Email: $\quad$ adnanrajib@ce.buet.ac.bd

Dr. Md. Mujibur Rahman, Professor at the Bangladesh University of Engineering and Technology.

Research interest: Climate change, environmental sanitation and water supply, urban storm drainage, surface water pollution management, EIA, environmental management system, indoor air pollution.

Address: Bangladesh University of Engineering and Technology,

Tel: $\quad$ +88-01713002904

Email: mujib@ce.buet.ac.bd 


\title{
Ciklonų pokyčiai ir klimato kaitos prognozės Bangladešo priekrantès regionuose
}

\author{
SM M. Rana, Md. Kamruzzaman, M. A. Rajib, Md. M. Rahman \\ Bangladešo inžinerijos ir technologiju universitetas
}

(gauta 2011 m. balandžio mèn.; atiduota spaudai 2011 m. birželio mèn.)

\begin{abstract}
Klimato pokyčiai keičia klimatinių reiškinių pobūdị. Ekstremalūs klimatiniai reiškiniai tampa dažnesni. Straipsnyje aiškinama klimato kaitos įtaka ciklonų charakteristikų pokyčiams Bangladešo regione 1975-2009 m. laikotarpiu. Tyrimas parodè, kad ciklonų dažnèja ir jie stiprèja. Nustatyta, kad silpnesni ciklonai pasikartoja rečiau, silpnesni ciklonai intensyvèja. Todèl manoma, kad ateityje ciklonų intensyvumo skirtumas bus dar didesnis. Straipsnyje pateikiamos rekomendacijos Bangladešo priekrantès regiono gyventojams, kaip prisitaikyti prie intensyvèjančių ciklonų aplinkos.
\end{abstract}

